\title{
Long term objective lip assessment following electrical burns to the oral commissure in infancy and childhood
}

\author{
Mohammed M Al-Qattan MB BS FRCSC, D Gillett MD, Hugh G Thomson MD MS FRCSC FACS \\ Division of Plastic Surgery, The Hospital for Sick Children, Toronto, Ontario
}

\begin{abstract}
MM Al-Qattan, D Gillett, HG Thomson. Long term objective lip assessment following electrical burns to the oral commissure in infancy and childhood. Can J Plast Surg 1996;4(2):89-93. Long term lip assessment was performed in 10 patients who sustained electrical burns to the oral commissure in childhood with a mean follow-up time of 15 years. None of the patients had any subjective symptoms and all were happy with the cosmetic appearance of the lips. Objectively, the lip elasticity index was within normal limits in all patients, but the soft tissue gap between the lips with maximum mouth opening was slightly below normal in $50 \%$ of patients. At rest, all patients had symmetric commissure positions. However, with wide grin, the injured commissure moved to a lesser extent than the uninjured side. Using the pommeter, the sphincteric power of the orbicularis oris was found to be within the normal range in all patients. Although none of the patients had any subjective sensory abnormalities of the lips, $50 \%$ of patients were found objectively to have a higher two-point discrimination and pressure threshold values in the injured commissure than the contralateral uninjured side.
\end{abstract}

Key Words: Electrical burn, Lip, Oral commissure

\section{Évaluation objective à long terme des lèvres après brûlures électriques à la commissure chez des nourrissons et des enfants}

RÉSUMÉ: Une évaluation à long terme des lèvres a été effectuée chez 10 patients ayant subi des brûlures électriques à la commissure durant l'enfance, la durée moyenne du suivi s'échelonnant sur 15 ans. Aucun des patients ne présentait le moindre symptôme subjectif; ils étaient tous heureux de l'aspect esthétique de leurs lèvres. Objectivement, l'indice d'élasticité des lèvres se situait dans les limites de la normale chez tous les patients, mais l'écart des tissus mous à l'ouverture maximum de la bouche était légèrement sous la normale chez $50 \%$ des patients. Au repos, tous les patients présentaient des positions symétriques de la commissure. Toutefois, le sourire large révélait une légère diminution de la mobilité du côté atteint. Vérifiée à l'aide d'un appareil à cette fin (pommeter), la puissance du sphincter de la bouche s'est révélée être dans les limites de la normale chez tous les patients, bien qu'aucun n'ait présenté de maladie sensorielle subjective au niveau des lèvres. Chez $50 \%$ des patients, on a noté une discrimination spatiale et un seuil de pression plus élevés du côté atteint que du côté controlatéral indemne.

$\mathrm{E}$ lectrical burns of the oral commissure are the most common type of electrical burns in infants and children $(1,2)$. The degree of tissue damage at the commissure ranges from mild to severe with multiple debilitating sequelae (3). Mild cases sustain second degree burn of the red lip only and spontaneous healing occurs with no or minimal deformity. In children with moderate tissue damage, there is full thickness burn at the commissure involving the red lip with or without a small area of adjacent skin. These patients are best treated with early splinting (4-10), but commissure plasty $(5,11,12)$ will be required in some cases either because of noncompliance with the use of the splint or because of late presentation

Correspondence and reprints: Dr HG Thomson, Division of Plastic Surgery, The Hospital for Sick Children, 1524-555 University Avenue, Toronto, Ontario, M5G 1X8. Telephone 416-597-0815, fax 416-813-6147 after injury. Severe cases have extensive tissue destruction, require flap coverage $(1,3,5,11)$ and have significant life-long cosmetic and functional problems.

In this paper we present long term objective lip assessment following electrical burns to the oral commissure in infancy and childhood.

\section{PATIENT POPULATION}

The medical records of 79 cases of oral electrical burns who were treated by the senior author (HGT) between 1968 and 1986 at The Hospital for Sick Children were reviewed. Out of the 79 cases, 46 had isolated unilateral oral commissure burns. Several efforts were made to contact these patients by telephone and letter, but only 10 patients responded and came for assessment. The data on these 10 patients are shown in Table 1. The first eight patients had moderate injury 
TABLE 1: Data of 10 patients with electrical burn of the oral commissure

\begin{tabular}{|c|c|c|c|c|c|c|}
\hline \multirow[b]{2}{*}{ Number } & \multirow[b]{2}{*}{ Sex } & \multicolumn{4}{|c|}{ Age (years) at time of: } & \multirow[b]{2}{*}{ Follow-up time* } \\
\hline & & Injury & Commissuroplasty & Revision surgery & Assessment & \\
\hline 1 & $M$ & 2 & 2 & 3 & 22 & 19 \\
\hline 2 & M & 3 & 4 & 7 & 20 & 13 \\
\hline 3 & M & 3 & 9 & NP & 22 & 13 \\
\hline 4 & $\mathrm{~F}$ & 1 & 7 & NP & 20 & 13 \\
\hline 5 & M & 1 & 2 & NP & 11 & 9 \\
\hline 6 & M & 1 & 1 & 7 & 16 & 9 \\
\hline 7 & M & 1 & 1 & 2 and 14 & 33 & 19 \\
\hline 8 & $\mathrm{~F}$ & 1 & 2 & NP & 25 & 23 \\
\hline 9 & M & 6 & NP & NP & 17 & 11 \\
\hline 10 & $\mathrm{~F}$ & 2 & NP & NP & 21 & 19 \\
\hline
\end{tabular}

${ }^{*}$ Follow-up time is in years since the last surgical procedure (for cases 1 to 8 ) or since injury (cases 9,10). F Female; M Male; NP Surgery was not performed

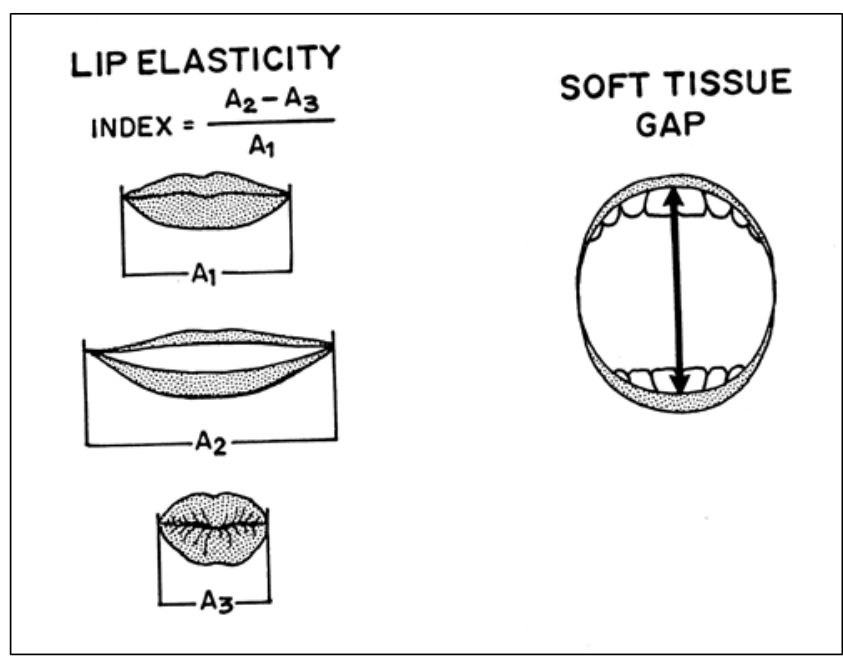

Figure 1) Lip elasticity index and soft tissue gap

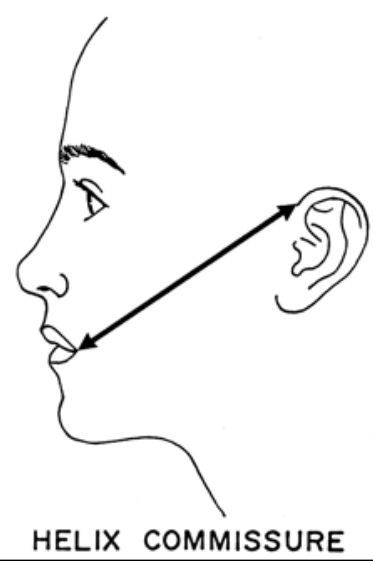

Figure 2) Helix commissure distance

and required commissuroplasty with or without subsequent revision surgery. The last two patients (cases 9,10) had mild injury and did not require any splinting or surgery. The average follow-up time for all cases was 15 years (range nine to 23 years).

\section{METHODS OF ASSESSMENT}

Each patient was asked if any subjective symptoms such as numbness, drooling, speech and mastication problems existed. The lip appearance was rated by the examiner (MMAQ) either as normal or with mild, moderate or severe visible scarring.

Objectively, the following parameters were studied.

Lip elasticity: Lip elasticity (Figure 1) was assessed using the lip elasticity index $=\frac{A 2-A 2}{A 1} \times 100$ where $\mathrm{Al}$ is the intercommissural distance (ICD) at rest while the subject is swallowing, A2 is the ICD with a wide grin, and A3 is the ICD in a purse position. The index value for each patient was compared with normal values given by Fogel and Stranc (13).

Soft tissue gap: Soft tissue gap of the lips (Figure 1) is defined as the straight line distance between the wet-dry line in the centre of the upper lip and the wet-dry line in the centre of the lower lip while the mouth is opened as widely as possible.

The value for each patient was compared with normal values given by Fogel and Stranc (13).

\section{Symmetry of positions of the right and left commissure:} The helix-commissure distance (Figure 2) was taken for the injured and uninjured commissure at rest and with wide grin. Patients with a difference of $3 \mathrm{~mm}$ or less between the two commissures were considered to have adequate symmetry. Patients with a difference of $4 \mathrm{~mm}$ or more were considered to have asymmetric commissure positions. The $3 \mathrm{~mm}$ difference limit is based on the fact that normal subjects are known to have an average of $3 \mathrm{~mm}$ in the amount and direction of the right and left facial commissure movements (14).

Lip sensibility: Assessment of sensation of the commissure was carried out using the static two point discrimination test (The Disk Criminator, Maryland) and the Semmes-Weinstein monofilament test (North Coast Medical Inc, California). Sensibility values of the injured commissure in each patient were compared with the values of the contralateral commissure. 


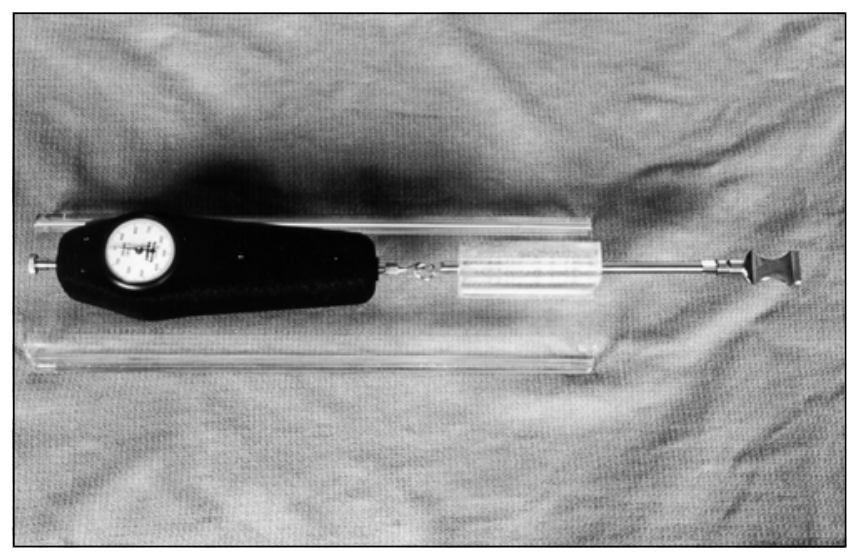

Figure 3) The pommeter (The peri-oral-muscle-meter)

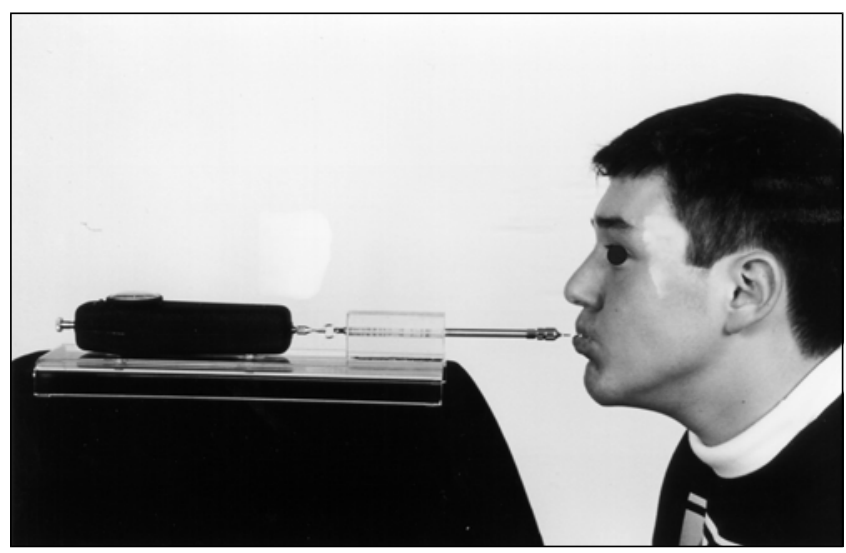

Figure 4) The pommeter in use

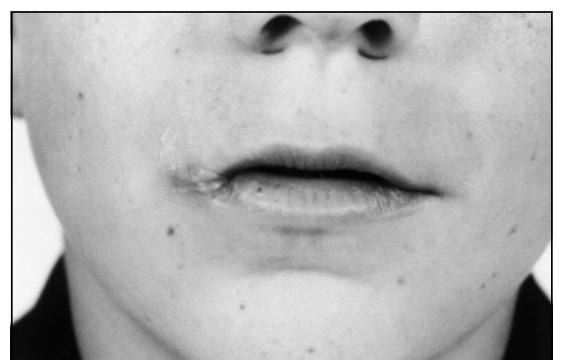

A

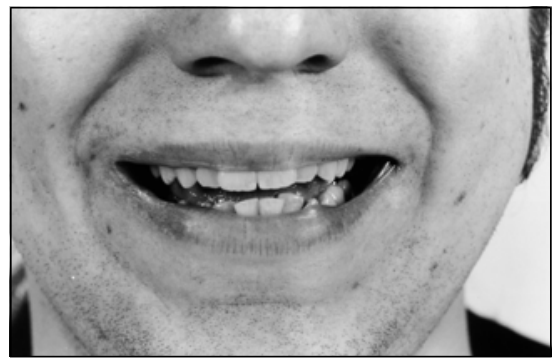

$D$

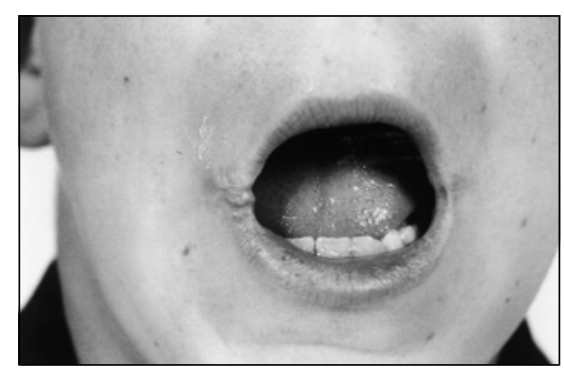

$B$

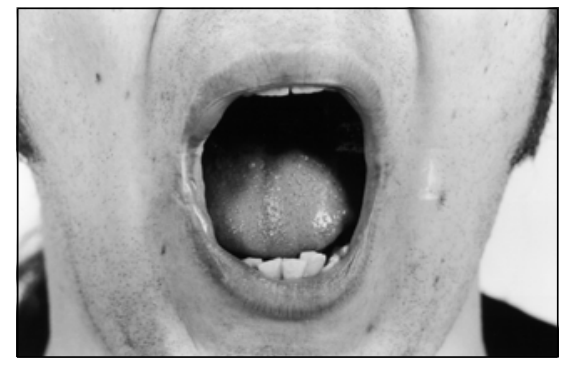

E

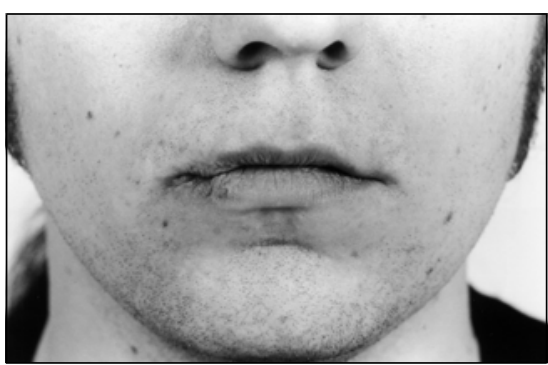

C

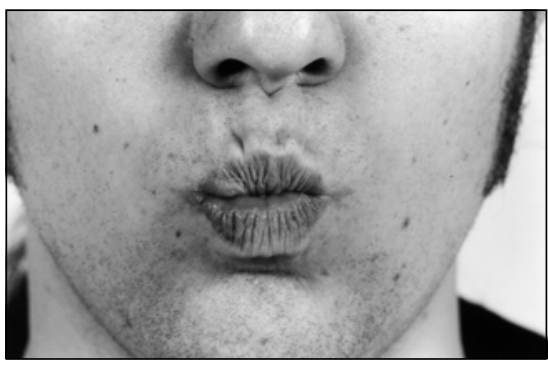

F

Figure 5) Case illustration (case 3). An electrical burn of the right oral commissure sustained at three years old. No splinting was used. He presented to the senior author (HGT) at nine years at which time commissuroplasty was performed. A,B Preoperative pictures at nine years old. C,D,E,F Postoperative pictures at 22 years old

TABLE 2: Lip elasticity index and soft tissue gap values

\begin{tabular}{cccc} 
Number & Age/sex & $\begin{array}{c}\text { Lip elasticity } \\
\text { index }\end{array}$ & $\begin{array}{c}\text { Soft tissue gap } \\
(\mathbf{m m})\end{array}$ \\
\hline 1 & $22 / \mathrm{M}$ & 62 & $51^{*}$ \\
2 & $20 / \mathrm{M}$ & 57 & $48^{*}$ \\
3 & $22 / \mathrm{M}$ & 59 & $56^{*}$ \\
4 & $20 / \mathrm{F}$ & 63 & $45^{*}$ \\
5 & $11 / \mathrm{M}$ & 56 & $40^{*}$ \\
6 & $16 / \mathrm{M}$ & 62 & $49^{*}$ \\
7 & $33 / \mathrm{M}$ & 56 & 51 \\
8 & $25 / \mathrm{F}$ & 64 & 50 \\
9 & $17 / \mathrm{M}$ & 62 & 56 \\
10 & $21 / \mathrm{F}$ & 61 & 49 \\
\hline
\end{tabular}

${ }^{*}$ alues below the normal range for the same sex and age group (13)
TABLE 3: Lip symmetry in the wide grin position

\begin{tabular}{ccc}
\hline Number & Age/sex & $\begin{array}{l}\text { Difference }(\mathbf{m m}) \text { between the right } \\
\text { and left helix-commissure distances } \\
\text { in the wide grin position }\end{array}$ \\
\hline 1 & $22 / \mathrm{M}$ & $4^{*}$ \\
2 & $20 / \mathrm{M}$ & $4^{*}$ \\
3 & $22 / \mathrm{M}$ & 2 \\
4 & $20 / \mathrm{F}$ & $4^{*}$ \\
5 & $11 / \mathrm{M}$ & 2 \\
6 & $16 / \mathrm{M}$ & $5^{\star}$ \\
7 & $33 / \mathrm{M}$ & 3 \\
8 & $25 / \mathrm{F}$ & 1 \\
9 & $17 / \mathrm{M}$ & 2 \\
10 & $21 / \mathrm{F}$ & 0 \\
\hline
\end{tabular}

${ }^{*}$ Patients in which the right and left commissures were considered to be asymmetric in the wide grin position 
TABLE 4: Lip sensibility measurements

\begin{tabular}{|c|c|c|c|c|c|}
\hline Number & Age/sex & \multicolumn{2}{|c|}{ Average two-point discrimination in $\mathrm{mm}$ at: } & \multicolumn{2}{|c|}{ Average pressure threshold in $\mathrm{g} / \mathrm{mm}$ at: } \\
\hline 1 & 22/M & 6 & 6 & 3.25 & 3.25 \\
\hline 3 & 22/M & 6 & 5 & 3.33 & 1.45 \\
\hline 4 & $20 / F$ & 4 & 4 & 1.45 & 1.45 \\
\hline 5 & $11 / \mathrm{M}$ & 3 & 3 & 1.45 & 1.45 \\
\hline 7 & 33/M & 6 & 5 & 2.35 & 1.45 \\
\hline 8 & $25 / F$ & 6 & 5 & 3.25 & 1.45 \\
\hline 9 & $17 / \mathrm{M}$ & 4 & 3 & 1.45 & 1.45 \\
\hline 10 & $21 / \mathrm{F}$ & 5 & 5 & 3.25 & 3.25 \\
\hline
\end{tabular}

Pressure threshold values are obtained by converting manufacturer's markings of the Semmes-Weinstein monofilaments into 'stress' values as described by Levin et al (19)

Sphincter power: The maximum strength of the orbicularis oris was measured using the pommeter (Figure 3). This instrument is a strain gauge developed by Posen $(15,16)$ of Toronto and was later used by Stranc $(17,18)$ of Winnipeg to assess lip function. With the mouth and pommeter held in the same horizontal plane, and after the teeth are placed in normal occlusion, the subject is asked to grip the mouth with the lips only (Figure 4) and to exert as much sphincteric pressure as possible. The pommeter is then stabilized and the head is pulled back. The power of the contracting lips obtained by each patient was compared with normal values in children (16) and adults (13).

\section{RESULTS}

None of the patients had any subjective symptoms and all were happy with the cosmetic appearance of the lips (Figure 5). Subjectively, the examiner rated all 10 cases to have 'mild visible scarring' of the commissure area. Objective assessment of lip parameters showed the following.

Lip elasticity index: All patients obtained values within the normal range (Table 2) (13).

Soft tissue gap: Fifty percent of patients had values below the normal range (13) (Table 2).

Symmetry of positions of the right and left commissures: At rest, all patients were considered to have symmetric commissure positions (ie, a difference of $3 \mathrm{~mm}$ or less between the right and left helix commissure distances). However, with a wide grin, the injured commissure moved to a lesser extent when compared to the uninjured commissure leading to asymmetry in four patients (Table 3 ).

Lip sensibility: Fifty percent of patients had slightly worse sensibility (ie, larger two point discrimination or higher pressure threshold values) of the injured commissure than of the contralateral uninjured side (Table 4).

Sphincteric power: All patients obtained pommeter readings within or above the normal range of orbicularis oris strength of the corresponding sex and age group $(13,16)$ (Table 5).
TABLE 5: Strength of orbicularis oris

\begin{tabular}{ccc}
\hline Number & Age/sex & Pommeter reading $\mathbf{( g )}$ \\
\hline 1 & $22 / \mathrm{M}$ & 360 \\
2 & $20 / \mathrm{M}$ & 400 \\
3 & $22 / \mathrm{M}$ & 450 \\
4 & $20 / \mathrm{F}$ & 600 \\
5 & $11 / \mathrm{M}$ & 250 \\
6 & $16 / \mathrm{M}$ & 300 \\
7 & $33 / \mathrm{M}$ & 550 \\
8 & $25 / \mathrm{F}$ & 410 \\
9 & $17 / \mathrm{M}$ & 360 \\
10 & $21 / \mathrm{F}$ & 290 \\
\hline
\end{tabular}

\section{DISCUSSION}

To our knowledge, detailed long term objective lip assessment following commissure electrical burns in childhood has not been reported. The $50 \%$ of patients who had a soft tissue gap value below the normal range did not have any aesthetic or functional problems because the values were only a few $\mathrm{mm}$ below the normal means of the corresponding sex and age groups (13).

The fact that the commissure positions were symmetric at rest in all patients, but not with wide grin, indicates that asymmetry was due to inadequate movement of the injured and scarred commissure rather than improper location of the commissure itself. Guidelines for finding the location of oral commissure before reconstruction are done in the rest position. If a normal commissure remains, measurements are taken from the midline to the normal side and then transposed to the abnormal side. If one does not have this option, then perpendiculars from the media limbus are used as guidelines (20).

Although none of the patients had any subjective sensory complaint abnormalities of the lips, $50 \%$ of patients were found objectively to have slightly higher two point discrimination and pressure threshold values. This suggests that in our patient group, sensory recovery after the electrical burn and commissuroplasty was incomplete, but was still adequate enough to mask any subjective feelings of alteration of sensory function.

This interpretation was given in other studies of sensory 
morbidity of the lips after orthognathic surgery (21). One year after LeFort I osteotomy, all patient groups show a higher mean two point discrimination of the upper lip than preoperative values. However, none of the patients were aware of any alteration of sensory function of the lip (21).

\section{REFERENCES}

1. Thomson HG, Juckes AW, Farmer AW. Electric burns to the mouth in children. Plast Reconstr Surg 1965;35:466-77.

2. Leake JE, Curtin JW. Electrical burns of the mouth in children. Clin Plast Surg 1984:11:669-83.

3. Ortiz-Monasterio F, Factor R. Early definitive treatment of electrical burns of the mouth. Plast Reconstr Surg 1980;65:169-76.

4. Colcleugh RG, Ryan JE. Splinting electrical burns of the mouth in children. Plast Reconstr Surg 1976;58:239-41.

5. Thomson HG. Electrical burns to the mouth. In: Feller I, Grabb WC, eds. Reconstruction and Rehabilitation of the Burned Patient. Ann Arbor: National Institute for Burn Medicine, 1979:216-22.

6. Silverglade D, Zacher JB, Ruberg RL. Improved splinting of oral commissure burns: Results in 21 consecutive patients. Ann Plast Surg 1982;9:316-20

7. Dado DV, Polley W, Kernahan DA. Splinting of oral commissure electrical burns in children. J Pediatr 1985;107:92-5.

8. Silverglade D, Ruberg RL. Nonsurgical management of burns to the lips and commissures. Clin Plast Surg 1986;13:87-94.

9. Sadove AM, Jones JE, Lynch TR, Sheets PW. Appliance therapy for perioral electrical burns: A conservative approach. J Burn Care Rehabil 1988;9:391-5

10. Barone CM, Hulnick SJ, de Linde LG, Sauer JB, Mitra A. Evaluation of treatment modalities in perioral electrical burns. J Burn Care Rehabil 1994; $15: 335-40$

11. Pitts W, Pickrell K, Quinn G, Massengill R. Electrical burns of the lips and mouth in infants and children. Plast Reconstr Surg 1969;44:471-9.

12. Su CT, Manson PN, Hoopes JE. Electrical burns of the oral
Finally, normal pommeter readings indicated that the traumatic insult to the orbicularis oris muscle in our patients was not sufficient to affect its sphincteric power.In conclusion, our study demonstrates a satisfactory long term outcome following mild and moderate electrical burns of the oral commissure.

commissure: Treatment results and principles of reconstruction. Ann Plast Surg 1980;5:251-9.

13. Fogel ML, Stranc MF. Lip function: A study of normal lip parameters. Br J Plast Surg 1984;37:542-9.

14. Paletz JL, Manktelow RT, Chaban R. The shape of a normal smile: Implications for facial paralysis reconstruction. Plast Reconstr Surg 1994;93:784-9.

15. Posen AL. The influence of maximum perioral and tongue force on the incisor teeth. Angle Orthodontist 1972;42:285-309.

16. Posen AL. The application of quantitative perioral assessment to orthodontic case analysis and treatment planning. Angle Orthodontist 1976;46:118-43.

17. Stranc MF, Page RE. Functional aspects of the reconstructed lip. Ann Plast Surg 1983;10:103-11.

18. Stranc MF, Fogel ML. Lip function: A study of oral continence. Br J Plast Surg 1984;37:550-7.

19. Levin S, Pearsall G, Ruderman RJ. Van Frey's method of measuring pressure sensibility in the hand: An engineering analysis of the Weinstein-Semmers pressure aesthesiometer. J Hand Surg 1978;3:211-6.

20. Achauer BM. Lip and mouth reconstruction. In: Achauer BM, ed. Burn Reconstruction. New York: Thieme Medical Publishers, 1991:64-78.

21. Posnick JC, Al-Qattan MM, Pron G. Facial sensibility in adolescents with and without clefts 1 year after undergoing LeFort I osteotomy. Plast Reconstr Surg 1994;94:431-5. 